\title{
SOME THEORETICAL ASPECTS OF ECONOMIC INTEGRATION
}

\section{Alem Merdić Hasan Mahmutović}

Review paper

DOI:10.21554/hrr.091711

University of Zenica, Faculty of Economics, Bosnia and Herzegovina

Received: 01.08.2017

Accepted: 03.09.2017

\begin{abstract}
One of the basic links of the process of globalization are economic integrations. The aim of this paper is to systematize theoretical achievements and to review the forms, effects and conditions for connecting countries motivated by economic benefits. In addition to the theoretical review of the conceptual definition of economic integration, the focus is on the levels of economic integration from the free-trade zone to the monetary and fiscal union, explaining the specificity of each of the mentioned levels. Considering that the connection between countries always raises the question of the benefits and costs of connection, the special emphasis in this paper is placed on the potential effects for free trade. Finally, the greatest contribution of this paper is the systematization and theoretical review of the theory of optimal currency area and monetary integration, which is especially significant for the European soil, taking into account the already established European Monetary Union.
\end{abstract}

Keywords: forms of economic integration, effects of economic integration, theory of optimal currency area. JEL: F15

\section{INTRODUCTION}

The perception of economic integration, and the interpretation of the effects of concrete integration depends on the level at which the integration itself takes place. Theoretically and empirically, several levels of integration are analyzed which, depending on the strength of the established connections between member states, and the degree of transfer of national competencies to the integration of the formed institution, give different results and effects reflected in the costs and benefits of integration. In order to form some kind of integration among countries, the countries of the integration process must be guided by some motives.

In modern economic integration, the most common integration motives are reflected in the resulting economic and political, usually, positive effects of integration. But besides economic and political motives, there are, and especially from the 18th to 20th century expressed, violent (through colonial

integration, when the "law of the stronger" ruled), and military motives of integration. But the subject matter of this paper will be the dominant economic integration motives, and in accordance with this, there are four different levels of integration: the free-trade zone, the customs union, the common market and the economic and monetary community or union.

Each of the above levels of integration, from the lowest to the highest, results in certain benefits and costs of integration, which primarily depend on the level of preparedness and development of the country that enters the integration processes. This means that, by default, every aspect of economic integration will not benefit if the potential member of integration has not readily entered the integration, with the maximum use of comparative advantages, and by the prepared internal forces to fight the pressure of competition coming from the member states.

\footnotetext{
$\overline{{ }^{1} \text { Correspodence to: }}$

Alem Merdić, MA, University of Zenica, Faculty of Economics, Bosnia and Herzegovina

Phone: +387 61826021

E-mail: alem.merdic@ef.unze.ba
} 
Therefore, the realization of economic integration motives, reflected through the improvement of economic activity through increased productivity, innovation and technological progress, the mobility of production factors, and ultimately more equitable distribution of wealth and the growth of the standard of living of the population, must be supported by structural changes and adequate preparation, not only for the formal membership, but also for essential and positive economic integration of the country. It is both theoretically and empirically proven that the economic integration has positive effects, which does not call into question the need for the integration of countries, but the problem of the will of the developed member states to make the integration useful for all members by conducting a just regional policy, which will result in a humane and fair distribution of the created wealth, that is, the convergence of the states of integration.

\section{METHODS}

In this paper, during the research, appropriate scientific-research methods were used: deduction, induction, synthesis, comparison and dichotomy as a form of specialization. Since the research carried out relates to theoretical aspects of economic integration, literary materials in the area of economic integration as a research base have been used, and appropriate research papers and internet sources have been used for the purpose of a more detailed theoretical coverage of economic integration and their potential effects.

\section{THE THEORY OF ECONOMIC INTEGRA- TION}

The notion of integration refers to consolidating, or connecting smaller entities into a larger system, in order to exploit the benefits carried by the functional interconnection. However, any kind of democratically based integration (political, military, economic, etc.) does not arise in itself, but is the result of positive expectations of separate entities in the integration process, and these expectations are reflected in the quantitative and qualitative expected benefits of integration. The case study of this paper are the economic reasons for integration, which result in the creation of economic integration, which, besides achieving positive economic results, manifested in the improvement of key macroeconomic variables of the linking entities, significantly contributes indi- rectly to achieving other goals. Accordingly, the economic reasons for integration and economic integration stand out as a prerequisite for the success of any other form of integration between countries. Bearing in mind the above mentioned, there are many definitions of economic integration, and in this paper, two definitions given by El-Agra are distinguished:

„Economic integration implies the agreement of two or more states on common goals and the pursuit of a common policy." (El-Agraa, 1982, p. 8)

„Economic integration implies a state or process that involves the fusion of individual economies into larger regions" (El-Agraa, 1982, p. 9)

It is important to note that economic integration, but also any other, does not necessarily have to be profitable, and that any economic integration does not mean improving the value of macroeconomic variables, on the contrary, negative movements are possible. The degree to which a country will benefit from economic integration depends on its internal readiness to connect and open the borders. This implies that the realization of the planned economic integration goals that can be seen in the increase in GDP due to market growth, productivity growth, technological improvements, the mobility of production factors, innovations, and the improvement of the balance of trade balance and current account must be supported by structural changes and adequate preparation internaly, which will be based on an efficient public administration, targeting the key sectors on which growth is based and maximizing the competitiveness of these sectors, by exploiting comparative advantages, favorable business environment and other elements of the competitiveness of the economy.

Different types of linking countries into specific trading blocks, regardless of the strength of the established link, represent only one part of the overall process of the globalization of gainful employment with a tendency to create a single world market. ${ }^{2}$ Theoreticians of international economy, including Nobel Prize-winning Paul Krugman, argue that total global welfare will reach its peak in the event of the removal of all barriers in trade relations between countries, which certainly represents one of the strong arguments of the continuation of globalization.

\footnotetext{
${ }^{2}$ This is unlikely to happen, due to the contradictory interests of the bearers of the process of globalization (primarily the US, China, Russia and the EU), as well as the inability to reach a consensus on the paths of globalization, as well as determining the leader of the entire process.
} 
However, the globalization process also has its opponents, who strongly advocate obstruction of the entire process, since they consider it to result in an uneven distribution of wealth and the loss of national sovereignty of individual states, leading them to be unable to independently regulate internal issues. The uneven distribution of wealth implies that the level of well-being measured by GDP p.c. will be at the level of the established integration, but that this GDP p.c. means the average GDP p.c. at the level of established integration, which means that regional development disproportions can occur, and the enrichment of certain parts at the expense of others, or the concentration of growth in the narrow space, which is, of course, theoretically not the aim. In addition to the above mentioned, one of the arguments of the opponents of globalization is the view that globalization will lead to the exploitation of workers in lowincome and developing countries in favor of largescale capital from highly developed countries.

The level of economic integration determines the strength of the relationship between the integration of the associated countries. Cooperation and liberalization of trade between countries can be done on a bilateral and multilateral basis. Bilateral trade cooperation between countries implies defining the terms of trade between the countries covered by the bilateral trade agreement, which does not require the liberalization of trade. Therefore, the level of liberalization of the country is agreed upon depending on their development and the development of mutual relations, because in the case of good bilateral relations, the more developed country can make certain concessions to the less developed country (eg voluntary limitation of exports, specify a preferential customs tariff, provided that it is not a member of a higher degree of integration by which it would transfer those competencies to supranational institutions). Multilateral agreements, too, do not necessarily mean full liberalization of trade, but define the trade relationship between several countries, and at least three. Economic integration is usually done formally at the multilateral level, and depending on the degree of complexity and strength of the connection, it can be: a free-trade zone, a customs union, a common market, an economic and monetary union, and a political union.

The free-trade zone is a form of linking countries that regulate trade relations between two or more countries, which involves the liberalization of trade in goods and services (the gradual reduction and elimination of customs and non-customs barriers) between the free-trade zone countries, and each of the Member States retains its discretion to independently determine customs tariff to the countries that are not Member States of the zone. The characteristic of the free-trade zone is that it is relatively easy to organize politically, because of the possibility of retaining the right to set tariffs for non-members of the zone, It is not difficult to arrange political regulation of mutual trade between minimum two countries. However, the problem of the free-trade zone lies in the administrative difficulties of determining the origin of the product (adjusted according to: Krugman, Obstfeld, Melitz, 2012). For example, assume that a free-trade zone was established between Bosnia and Herzegovina, Serbia and Macedonia. The free-trade zone regulates the mutual relations and trade liberalization between the members of the zone. Let's also assume that Bosnia and Herzegovina has good bilateral relations with Turkey, and consequently applies low customs rates on imports of products from Turkey, and that Macedonia applies high customs rates on imports of products from Turkey. How can products from Turkey be found on the Macedonian market? A producer from Turkey who wants to place his product on the market of Macedonia can make most of the products in Turkey, and at a low customs rate export them to Bosnia and Herzegovina, and then in Bosnia and Herzegovina he can finalize and obtain a certificate of origin confirming that the product originates in Bosnia and Herzegovina. Then, due to the liberalization of trade between Bosnia and Herzegovina and Macedonia, which is a consequence of membership in the free trade zone, the product will be exported to the Macedonian market. The problem occurs at the border of Macedonia with the actual determination of the origin of products, and the prevention of possible abuse, especially if the product has a certificate of origin of a member country of the free-trade zone. An example of a free trade zone is CEFTA $2006^{3}$. The customs union is a higher degree of integration in relation to the free-trade zone. The specificity of the customs union is reflected in the liberalization of trade (reduction and abolition of trade barriers) between the member states of the union and the application of the single customs tariff on imports from third countries.

${ }^{3}$ Eng. Central European Free Trade Agreement. 
In this way, a part of the national sovereignty is shifted to the integration of the formed institution. The customs union solves the problem of determining the origin of products, given the unique customs tariff towards third countries, but it is much more difficult to politicaly establish the customs union in relation to the free-trade area (adjusted according to Krugman, Obstfeld, Melitz, 2012). The reason for this lies precisely in the common customs tariff towards third countries. Namely, if we return to the example mentioned in the free-trade zone, and suppose that the same countries formed a customs union, the question arises as to which tariff will apply to imports of products from Turkey, considering that we have assumed that Bosnia and Herzegovina has good bilateral relations with Turkey and apply low customs rates on imports of Turkish products, assuming that Macedonia applies high customs rates on imports of products from Turkey. It is logical that Bosnia and Herzegovina will push for lower, and Macedonia for higher customs rates. This problem usually exists at the beginning of the formation of a specific customs union, and each subsequent member of the customs union accepts a customs tariff that has already been established, since members of the formed customs union set it as a condition for membership in the union, except if the country claiming to be a member of the union is strong at negotiating and significant for the union that a customs tariff may be corrected at its request. The example of a customs union is MERCOSUR (a customs union in South America).

The next higher level of integration in relation to the customs union is the common market. The common market implies the economic integration of countries that, in addition to free trade between members, also includes the freedom of movement of people and capital, that is, the factor of production. So, it has all the traits of a customs union with the freedom of movement of the factors of production and people. Increased liberalization aims at improving the positive effects of integration processes. It is important to emphasize that with all the freedoms the equal status of all market participants is ensured, that is, a harmonized legislative framework at the level of integration guarantees everyone the same rights, but also obligations, regardless of national origin. In this sense, this type of integration according to the economic and legal order is not different from the arrangement of a state, only within the country; we have a single monetary and fiscal policy, and one currency, which is not the case in the common market. The best example of integration with the features of the common market is the Common Market of the European Union.

Fiscal and monetary union is the largest degree of economic integration. It implies harmonization of fiscal and monetary policies, and a single currency at the union level. So, it retains all the properties of the common market, with the addition of a single monetary and fiscal policy. The monetary policy is carried out by a joint central bank in coordination with the central banks of the member states, and the fiscal policy is formed by a joint government at the level of the fiscal union. It is important to note that the monetary union is ranked by the scale of economic integration below the fiscal union, that is, there can be only a monetary union, so that the member states of the monetary union form a fiscal union. In addition to harmonizing monetary policy, the fiscal union implies harmonization of fiscal policies and harmonization of tax regulations at the level of the whole union. Thus, a monetary union can exist without a fiscal union, that is, the rule is to form a monetary and then a fiscal union. The monetary union is characterized by the complete absence of foreign currency risk, which significantly improves the trade relations of the member states. An example of a monetary union is the European Monetary Union, while on the territory of Europe we do not have a fiscal union.

\section{RESULTS}

\section{Potential effects of economic integration}

Economic integration implies the gradual reduction and elimination of barriers to trade between countries, and the free movement of goods, services, people and capital, and in the highest degree of integration and the formation of a single central bank, the pursuit of a single monetary and fiscal policy. Therefore, by establishing a stronger link among the participants of the integration, certain resulting effects will be caused which will be analyzed in this part of the paper.

There are many arguments for free trade, based on potential effects, and the analysis of the costs and benefits of free trade, but the following three are especially distinguished (Krugman, Obstfeld, Melitz, 2012):

\section{Political argument for free trade}

2.Removing the loss of efficiency in production and consumption

3.Additional benefits from trade liberalization 
The political argument for free trade, and at the same time one can be interpreted as one of the potential effects of integration, is based on the fact that the state of free trade is better than the absence of the same. The reason for this lies in the fact that in the case of protection there will be no protection for economic sectors characterized by dynamically growing yields, that is, economic sectors that, according to the theory of international trade, need protection, but the economic sector with the strongest political influence will be protected, given that the decision on protection is passed by the government and the parliament, which, in fact, are representatives of political parties. Therefore, free trade advocates consider, that it is better to release the freetrade activity as it will create a better state in relation to the situation caused by the politically biased protection of the sectors of economy that should not be the subject of the same.

The elimination of loss in efficiency in production and consumption is an argument of free trade which implies that it is better to secure free trade, as free trade will provide greater consumption of products and services, which is manifested as an increase in wealth, and at the same time it will be achieved and, overall, higher production to meet this demand. In other words, the introduction of customs increases the price of goods which leads to the growth of supply, but at the same time there is a decrease in demand and consequently consumption of products, which causes a decline in national well-being. This argument is particularly evident in the example of a small country, as shown in the following image.



Image 1 Argument of efficiency for free trade

Triangles labeled as distortion of production and distortion of consumption represent the net cost of introducing customs in the case of small countries. Given that the small country has no impact on the fall in the world price of products, there is a rise in prices for the entire amount of customs, so that the net effect of customs introduction causes a decline in wealth, which means that it is better to secure free trade for the growth of the welfare of a small country,because in this case the losses resulting from the distortion of production and consumption will be eliminated.

In addition to the aforementioned integration effects, the additional benefits of integration and free trade are manifested in the achievement of economies of scale, and the possibilities of learning, innovating and strengthening competitiveness. Namely, in case of existence of protection, production is less efficient and high profits are realized, which attracts a lot of companies in a protected economy sector, the production of each company decreases, which leads to an increase in the average cost and, consequently, product price growth and the reduction of welfare of the poster. In the case of free trade, only efficient producers who produce large quantities of products remain on the market, they achieve economies of scale, all of which lead to a fall in the sales price of products and the growth of consumer welfare at the level of integration. In addition, increased competition at the level of integration forces manufacturers to find new ways of production, which stimulates product innovation and production processes, all for the sake of survival in the market, thus ensuring the achievement of the most efficient production possible (adjusted according to: Krugman, Obstfeld, Melitz, 2012).

When it comes to establishing a customs union, Jacob Vinner performed an analysis of the effects of integration by defining two effects, of which, according to his analysis, it ultimately depends on whether there will be welfare growth. Those effects are: the effect of trade creation and trade diversion. 
The effect of trade creation involves the replacement of expensive domestic production and / or more expensive imports from the rest of the world,with imports from a Member State of the Union. In order to create a clearer picture, we will explain this in the following example. Suppose that Bosnia and Herzegovina produces potatoes at a price of $2 \mathrm{KM} / \mathrm{kg}$, Serbia at a price of $1.5 \mathrm{KM} / \mathrm{kg}$ and Macedonia at a price of $1 \mathrm{KM} / \mathrm{kg}$. In the event that Bosnia and Herzegovina has high customs rates on imports of potatoes from these countries, resulting in a higher price of imported potato than the domestic price, it will consume its potatoes. But if Bosnia and Herzegovina establishes a customs union with Serbia, it will import potatoes from Serbia at a price of $1.5 \mathrm{KM} / \mathrm{kg}$, thus replacing expensive domestic production with imports from the member state of the Union, and this effect implies the creation of trade, which leads to the growth of welfare due to Integration. However, if the customs duty on imports from Macedonia and Serbia before the creation of the customs union was $0.6 \mathrm{KM} / \mathrm{pc}$, Macedonian potatoes in Bosnia and Herzegovina cost $1.6 \mathrm{KM} / \mathrm{pc}$, while the Serbian potatoes cost $2.1 \mathrm{KM} /$ pc, and Bosnia and Herzegovina imports Macedonian potatoes at a price of $1.6 \mathrm{KM} /$ piece, without taking into account other costs. By establishing a customs union with Serbia it would be cheaper for Bosina and Herzegovina to import potatoes from Serbia at the price of $1.5 \mathrm{KM} /$ piece, because there is no customs duty. But in this case, the well-being of Bosina and Herzegovina will not increase, since $0.6 \mathrm{KM} /$ pc was the customs revenue that remained in Bosnia and Herzegovina, and Bosnia and Herzegovina pays $1.5 \mathrm{KM} / \mathrm{pc}$ to Serbia and the total amount of money goes to Serbia, while in Macedonia only $1 \mathrm{KM} / \mathrm{pc}$ was paid. This effect is known as the trade diversion effect and implies a decline in the welfare of the country by membership in the customs union.

\section{The theory of optimal currency area and mone- tary integration}

The question of establishing a higher level of integration of the countries in relation to the established common market, in order to continue the further absorption and increase the positive effects of interconnection, after World War II, initiated a debate on monetary convergence of the countries associated with the common market. Everything started with the work of Milton Friedman in 1953, entitled "The Case for Flexible Exchange Rates", which analyzes the method of potential monetary integration of countries, whether through a fixed or floating exchange rate, or whether to introduce a common currency, and hence, this work is the basis for further research of the monetary integration.

After considering Friedman's monetary integration, the first author who laid the foundations and first mentioned the theory of the optimal currency area, as a theory that should answer the question for which regions or region it is desirable to introduce a single currency or fix foreign exchange rates, and to have a unique monetary policy, and on the basis of a costbenefit analysis, was R.A. Mundell with his Theory of Optimum Currency Areas in 1961. After Mundell, there were R. I. McKinnon with the work of "Optimum Currency Areas" in 1963 and P. Kennen in 1969. In order to designate certain regions or countries as monetary integrated as an optimal currency area, it is necessary to ensure full employment, low inflation rate and balance in the balance of payments. There are several different definitions of the optimal currency area, and below are two definitions that best and most accurate describe the optimal currency area:

"... a region for which it is optimal to have its own currency and its own monetary policy; A region that is not even so small and open that it would be better to tie its currency to its neighbors, nor so great that it would be better to split it into sub-regions with different currencies "(Caves, Frankel, Jones, 2012)

" 'Optimum' has been used here to describe a optimal currency area in which monetary and fiscal policies and flexible foreign exchange rates can be used to provide the best solution (sometimes conflicting) of three tasks: (1) maintaining full employment; (2) maintenance of balanced international payments; (3) maintaining a stable, internal, average price level "(McKinnon, 1963).

Developing the Optimal Currency Area Theory, Mundell explains how to solve asymmetric shocks in the event of a currency area and in the case of different countries with national currencies that are not fixed. If we had the case of countries with different national currencies and separate monetary policies, demand shocks in one of these countries would have to be amortized in monetary co-ordination with another country. What does this mean? Before changing the supply and demand relationship, both countries are in balance. A decline in demand in one country, caused by a rise in demand for products from another country, leads the first country to a deficit situation, and causes unemployment to rise, and leads to a surplus of the other country and causes the emergence of inflation. 
This would imply that the first country, due to the reduction in domestic demand and the balance of payments deficit, must address the problem of unemployment growth in the help of another country. If the central bank of the affected country would lead an expansive monetary policy, thus depressing the national currency, this would increase the export competitiveness of the deficit country, which would compensate for the decline in domestic demand by exporting products to another country, provided that the other country, which is in oversupply, does not reduce the inflation by the decline in credit activity, or restrictive monetary policy. If there is a lack of a cooperative approach from the beneficial country, a deficit country would pay the caused shock with increased unemployment. This would mean that in order to solve the unemployment and inflation problem it is desirable that the two countries with different national currencies have a fluctuating exchange rate in order to make economic stabilization in case of asymmetric shocks. If, in any case, the above-mentioned asymmetric shock occurred within the countries associated with the monetary union, the resolution of the unemployment problem would be exclusively within the competence of the central bank and the willingness of the associated countries to solidarity, as the expansive monetary policy would solve the unemployment problem in a shocked country or region, but it would cause inflation in a region that is not affected by the asymmetric shock. If there are symmetrical shocks in the case of monetary union, the problem is solved by adjusting the foreign exchange rate to the rest of the world. Lastly, Mundell believes that for the full functioning of the currency area is necessary to ensure full labor mobility in order to, on the one hand, redundant workforce in the country in which demand is falling, migrate in a country with a surplus of demand, on the other hand, provided that the other country can produce the products for which the demand in the first country has fallen. Such a method of resolving shocks, in fact, is an alternative to monetary interventions, as labor migration would solve the problems of inflation and unemployment, but it is important to note that short-term shocks, due to migration costs, can not lead to migration, but also that these shocks must be resolved by monetary interventions. Since Mundell was the first to emphasize the importance of labor mobility in a monetary union, and thus found the theory of optimal currency areas, the criterion of labor mobility is called Mundell's criterion: "Opti- mum currency areas are those within which people move with ease"(Boldvin, Viploš, 2010).

Significant contribution to the development of the theory of optimal currency areas was given by R.I. McKinnon, who, for the analysis of the optimal currency area, takes the degree of openness of the economy, that is, the volume of foreign trade. His analysis shows that a country that has a higher proportion of goods that are internationally viable or that are the subject of international exchange should be used by a fixed exchange rate, because in the case of a fluctuating exchange rate, due to the shocks that cause the change in the exchange rate, this change would significantly affect the price stability and could cause disturbances in the balance of payments. This is particularly significant for a small country that has a large percentage of goods that are the subject of international exchange, since that country can not influence the movement of prices, and therefore, the inclusion of a small open economy in the currency area is proposed. On the other hand, a large economy with a small share of goods that are the subject of international exchange will not appreciably experience currency exchange rate disturbances in the balance of payment and price stability on the domestic market, and therefore it is proposed to use the fluctuating exchange rate, and eventual disruptions in the balance of payments can be corrected by a small reduction in consumption. If there are several countries that are open to trade, competition will create the price of the product, and in the mutual relationship lead to price equalization, so that the real exchange rates towards the rest of the world are identical for both countries, which means that for these countries it is more convenient to create an optimal currency area. Bearing in mind the above mentioned, the criterion that emphasizes the openness of economies for creating an optimal currency area is called McKinnon's criterion: "Countries that are very open to trade and to a large extent trade with each other form an optimal currency area“ (Boldvin, Viploš, 2010).

Peter Kenen of Princeton University continued to upgrade the optimal currency area theory. His contribution to the development of this theory is reflected in the introduction of a new criterion for the success and efficient functional functioning of the currency area, which is the diversification of production. Namely, Kenen believes that asymmetric shocks result in negative economic effects, and arise because countries or regions produce a variety of products. 
Therefore, if the countries or regions in question have a diversified economic structure, diversify production, occasional asymmetric shocks will not cause significant adverse effects, since negative effects can be annoyed by redirecting resources to other related industries on the one hand, and there will be no need for monetary interventions if countries have similar products, since each country will be approximately equally affected by these shocks, so that they will suffer losses equally, on the other hand. For the success of the currency area, it is also necessary to meet this criterion, which according to Kenen was named Kenen's criterion: "Countries that have wide diversified production and exports and which have a similar structure form an optimal currency area" (Boldvin, Viploš, 2010).

In addition to the aforementioned economic criteria, certain political criteria need to be fulfilled for the formation of the optimal currency area, as well (adjusted: Boldvin, Viploš, 2010):

1.Transfer criterion: countries that agree to help each other in the event of negative shocks form an optimal currency area;

2.Criterion of Homogeneity of Preference: Member States of the currency union should have a broad consensus on how to deal with shocks and

3.Solidarity criterion: When a common monetary policy raises a conflict of national interest, the countries that make up the currency area must accept costs in the name of a common fate.

Forming an optimal currency area with it has certain significant advantages, but if it is formed between countries with a lack of real convergence, it can also cause negative effects. The most important advantages of inclusion in the currency area are reflected in the following: increasing allocative efficiency due to the elimination of the exchange risk, and reduced risk coverage costs can result in increased international exchange and integration; Removing, partially or completely, the exchange risk may reduce interest rates on those markets where the exchange risk premium was included in the interest rate; The possibility of financing the deficit of the balance of payments with the local currency due to its convertibility, without the need to earn foreign exchange; Reduction of transaction costs; Some countries by entering the monetary union can achieve credibility as a result of abandoning their own monetary policy and their own currency (in this way it is possible to reduce the high rate of inflation in these countries); Reduced relative price variability (this argument is valid only if the prices of some commodities are more sensitive to the change in the exchange rate, and in the case of its fluctuation, they are fluctuated); Less susceptibility to speculative attacks (Hallwood, MacDonald, 2000).

The shortcomings that can be associated with accessing the currency area are reflected in the following (Koški, 2002):

1.If inflation is not stopped or the country approaches the currency area with an overestimated domestic currency rate, it can enter a period of high unemployment and reduced economic growth;

2.Relatively low-income countries can attract mainly direct low-value investments, while for high-income countries, the opposite is true. U odsustvu deviznog kursa izlaz mogu biti samo međuregionalni transferi. This means that due to the diversity of economic structures, countries are exposed to asymmetric shocks;

3. Withdrawal from inflation that can contribute to the reduction of public debt (if it is not indexed);

4.Monetary policy of the Union can be set up so that it does not gratify all members, as with interest rates, neither with the exchange rate. Furthermore, there is a problem of division of emission gain (seigniorage).

If we collectively look at the foregoing conditions for the existence of an optimal currency area, we can rightly ask whether the optimal currency area is only a theoretical model, and whether it is possible to create the same. The reason for this lies in the fact that in the 21 st century we have uneven development between certain regions within very small countries, and these underdevelopments are also conspicuous in large countries, which is the result of domestic political pressures on the development of individual parts or regions in order to neglect the equal development of all regions. This means that if a country is unable to meet, first and foremost, the political criteria in its territory, it will probably not be ready for consensus on the territory of the possible optimal currency area. An important condition for an optimal currency area is certainly a real convergence, which has not been achieved at the national level, which undermines the willingness of more developed countries to create an optimal currency area, since these countries would have to give up certain funds in order to more evenly distribute wealth, that is, the reduction of national development disproportions. Therefore, the formation of a currency area with all the defined criteria between several countries is not possible, and the question is whether it is possible at the level of one state. 
All this leads to the conclusion that it is desirable to create a monetary union and that these developed countries are ready, but with the aim of reducing costs and risks in mutual business, and more competitive approach to the rest of the world, but the optimal currency area is still at least on the European soil, far from realization.

\section{CONCLUSION}

The complete, forward-presented, analysis of economic integration, from the aspect of economic parameters, does not inevitably address the need for integration, since in the integrated space there will be improvements in the value of macroeconomic parameters. However, the question is how the dispersion of the created wealth will be carried out, and whether integration leads to the enrichment of the rich and the placing of a less competitive country in the function of further development of more developed members of integration. It is unlikely that the developed country, which enters the integration processes, will advocate for a just regional policy. This is supported by the fact that the developed countries at a national level do not respect the principles of balanced regional development, and the question is how is a country going to advocate for a fair regional policy on an international level when there are regional divergent development trends internally. Finally, it is important to conclude that any integration does not necessarily mean generating positive economic results, but that economic integration can contribute to the economic development of a member state if it achieves the appropriate degree of competitiveness on the internal plane and takes advantage of its comparative advantages in the integrated space.

\section{REFERENCES}

Boldvin, R., \& Viploš, Č. (2010), Economy of European Integration, third edition. Beograd: DATA STATUS.

Caves, R. E., Frankel, J. A., \& Jones, R. W. (2002). World Trade and Payments: An Introduction, 9th edition. Boston: Addison Wesley.

El-Agraa, M. D. (1982). International Economic Integration. London: Macmillan.

Hallwood, C. P., MacDonald, R. (2000). International Money and Finance, 3rd edition. Oxford: Blackwell Publishers Inc.

Koški, D. (2002). Fundamental questions of the theory of optimal currency areas. Economic News, Number 1 and 2 (15). Faculty of Economics in Osijek.

Krugman, P., Obstfeld, M., \& Melitz, M. (2012.) International Economics Theory \& Policy, Ninth edition. Boston: Pearson Education.

McKinnon, R. I. (1963.) Optimum Currency Areas. American Economic Review Vol. 53. No. 4. American Economic Association. Nashville. 